\title{
University Students' Perceptions about Teaching Ataturk's Principles and Turkish Revolution History with Distance Education
}

\author{
Bülent AKBABA $^{*}$ Selahattin KAYMAKCI ${ }^{* *}$ Togay Seçkin BİRBUDAK $^{* * *}$ \\ Bahadır KILCAN ${ }^{* * *}$
}

Received: 31 August 2014

Accepted: 09 May 2015

\begin{abstract}
This study aimed to reveal students' views regarding the teaching of the Atatürk's Principles and History of Revolution (APHR) course by distance education. The survey model was employed in the study. The study group consisted of 645 students attending Karadeniz Technical University and Karabük University. The research results showed that although the participants receiving the APHR course by distance education had a high level interest in history of revolution subjects, they had a low level participation in the APHR course. Most of the participants wanted the APHR course to continue to be taught at higher education level without any change in its content and name. The participants thought that the teaching of the Atatürk's Principles and History of Revolution accomplished its goals at medium and high levels. Among the problems encountered by the students in the APHR teaching by distance education, the most prominent ones were the inadequacy of the teaching methods employed, exam-oriented instruction, and the insufficiency of the teaching materials used. Traditional lecture and adhesion to textbook continued in distance education, too. It was seen that most of the participants receiving the APHR course by distance education did not attend the lessons regularly and thought that teaching the APHR course by distance education was not beneficial.
\end{abstract}

Keywords: Atatürk’s principles; history of revolution; distance education; university students

\section{Extended Abstract}

Purpose and Significance: This study aimed to reveal students' views regarding the teaching of the Atatürk's Principles and History of Revolution (APHR) course by distance education. It was considered significant to open up for discussion the functionality of distance education, which was regarded as an alternative tool for solving such problems experienced in the teaching of the APHR course as physical space problems, insufficiencies in exams, lack of lecturers, and inadequacies concerning the use of teaching methods and materials, in the teaching of the APHR course and to address its outcomes in consideration of face-to-face education.

\footnotetext{
*Corresponding Author: Assoc. Prof. Dr., Gazi University, Ankara, Turkey, akbaba@gazi.edu.tr

**Assoc. Prof. Dr., Kastamonu University, Kastamonu, Turkey, kaymakci37@yahoo.com

****Assist. Prof. Dr., Gazi University, Ankara, Turkey, togayar@gmail.com

${ }^{* * * *}$ Assist. Prof. Dr., Gazi University, Ankara, Turkey, bahadir@gazi.edu.tr
}

\section{Citation Information}

Akbaba, B., Kaymakcı, S., Birbudak, T. S., \& Kılcan, B. (2016). Üniversite öğrencilerinin uzaktan eğitimle Atatürk ilkeleri ve inkılap tarihi öğretimine yönelik görüşleri. Kuramsal Eğitimbilim Dergisi [Journal of Theoretical Educational Science], 9(2), 285-309. 
Methods: The survey model was employed in the study. The study group consisted of 645 students attending Karadeniz Technical University and Karabük University.

Results: Of the participants receiving the APHR course by distance education, $74.1 \%$ had medium and high level interests in Atatürk's Principles and History of Revolution subjects. $77.8 \%$ of the participants wanted the APHR course to continue to be taught at higher education level. $49.5 \%$ of the participants wanted the course to be elective. Of the participants, $72.2 \%$ did not want the content of the course to be changed, and $85.9 \%$ did not want the name of the course to be changed. $6.2 \%$ of the participants did not want the APHR course to be included in the curriculum.

Among the factors influential on such views of the study group, the most outstanding ones were as the following: the course did not have any impact on academic success; the course did not involve multiple perspectives; and the course was deprived of discussion and criticism. The participants thought that the teaching of the Atatürk's Principles and History of Revolution accomplished its goals at medium and high levels.

Among the problems encountered in the APHR teaching by distance education, the most prominent ones were the inadequacy of the teaching methods employed, examoriented instruction, and the insufficiency of the teaching materials used. The teaching method and the teaching material most frequently employed in the APHR course received by the participants by distance education were traditional lecture and textbook respectively.

$52.6 \%$ of the participants thought that the course had to be received by every Turkish citizen and explained the importance of national unity and solidarity. $10.7 \%$ of the participants stated that APHR did not mean anything to them. Among the participants receiving the APHR course by distance education, 89.3\% did not attend the lessons regularly, and $76.6 \%$ thought that teaching of the APHR course by distance education was not beneficial.

Discussion and Conclusions: According to the research results, the participants receiving the APHR course by distance education had a high level interest in Atatürk's Principles and History of Revolution subjects. The findings of Babaoğlu (2013) and Akbaba et al. (2014) support this result, too.

$33 \%$ of the study group attended most of the APHR lessons. That indicates that there was a low student participation in the APHR course by distance education that was considered an alternative to the APHR course in the classroom environment requiring attendance as an obligation.

According to the research results, $77.8 \%$ of the participants wanted the APHR course to continue to be taught at higher education level. The findings of Akbaba et al. (2014) support this finding, too.

$6.2 \%$ of the participants did not want the APHR course to be included in the curriculum by any means. Ozankaya (1978, p. 71) reported this percentage to be $2.3 \%$. 113 students 
(18.3\%) participating in Aksoy (2003, p. 157) told that they did not believe that the course was necessary. In Akbaba (2009), the number of students denoting that there must be no APHR course was 5. It referred to $0.4 \%$ of the sample group. Akbaba et al. (2014) reported that 5.5\% of the pre-service history teachers participating in the study said that there must be no APHR course at all. These results point to the necessity of teaching the APHR course in higher education institutions.

The participants thought that the teaching of the Atatürk's Principles and History of Revolution accomplished its goals at medium and high levels. This result is in parallel with the findings of Y1lmaz (2004), Akbaba (2007), and Akbaba et al. (2014).

Among the problems encountered by the students in the APHR teaching by distance education, the most prominent ones were the inadequacy of the teaching methods employed, exam-oriented instruction, and the insufficiency of the teaching materials used. This result shows parallelism with the findings reported by Gülmez (2003), Doğaner (2005), Akbaba (2008), and Akbaba et al. (2014). The results of the present study indicated that similar problems were experienced in the face-to-face APHR education provided in the classroom environment and in the APHR lessons provided through distance education. The fact that the same problems are encountered in the APHR course conducted by distance education that is considered a flexible and alternative learning environment involving information technology support demonstrates that the sources of the basic problems experienced in the teaching of the course are similar, and distance education fails to solve such problems.

The research results showed that the teaching method most frequently employed in the APHR lessons provided by distance education was traditional lecture. On-site visits, problem-solving, projects, and simulations were the teaching methods employed least frequently in the teaching of the APHR course. According to the results of other studies on this subject (Doğaner, 2005; Akbaba; 2008; Akbaba, 2009; Akbaba et al., 2014), the teaching method employed in the APHR lessons most frequently is traditional lecture. Though the learning-teaching environment changes, traditional lecture where lecturer is active and students are passive listeners continues to prevail in the APHR lessons. The usage frequency of other teaching methods that may contribute to the teaching of the course is not satisfactory in the distance education environment, as is the case in the face-to-face education environment.

The results of the current study also demonstrated that uniformity in the use of the teaching methods in the APHR lessons conducted through distance education manifested itself in the teaching materials used, too. The students used textbook as the primary source in the APHR lessons conducted through distance education. Ozankaya (1978), Gülmez (2003), Doğaner (2005), Akbaba (2009), and Akbaba et al. (2014) also revealed that textbook was the source employed in the teaching of the APHR course most frequently.

The examination of the participants' views regarding the functionality of conducting the APHR lessons by distance education indicated that $89.3 \%$ of the participants receiving the APHR course by distance education did not attend the lessons regularly, and $76.6 \%$ 
thought that teaching the APHR course by distance education was not beneficial. Distance education, which was used for overcoming such problems encountered in the teaching of the APHR course in higher education institutions as physical space problems, lack of lecturers, inadequacies concerning teaching methods and teaching materials, and problems about creating a shared information repository for common exams, was not adopted by the participants as it did not provide a mentality and an approach different from those offered by the face-to-face teaching of the course. Though the participants have a high level interest in the course, they do not consider the teaching of the APHR course by distance education functional because the advantages provided by information technology cannot be used sufficiently; lecturers fail to get rid of their roles as sources that transfer information; and the use of teaching methods and materials is unproductive. 


\title{
Üniversite Öğrencilerinin Uzaktan Eğitimle Atatürk İlkeleri ve İnkılap Tarihi Öğretimine Yönelik Görüşleri
}

\author{
Bülent AKBABA $^{*}$ Selahattin KAYMAKCI ${ }^{* *}$ Togay Seçkin BİRBUDAK $^{* * *}$ \\ Bahadır KILCAN $^{* * * *}$
}

Makale Gönderme Tarihi: 31 Ağustos 2014

Makale Kabul Tarihi: 09 Mayıs 2015

ÖZ: Bu araştırmanın amacı uzaktan eğitimle Atatürk İlkeleri ve İnkılâp Tarihi (AİIT) öğretimine yönelik öğrenci görüşlerini ortaya koymaktır. Tarama modelinde gerçekleştirilen araştırmanın çalışma grubunu Karadeniz Teknik Üniversitesi ve Karabük Üniversitesinde öğrenim gören toplam 645 öğrenci oluşturmaktadır. Araştırmanın sonuçlarına göre, uzaktan eğitimle AIIITT dersi alan katılımcıların inkılâp tarihi konularına ilgi düzeyi yüksek olmakla birlikte AİIT derslerine katılım düzeyleri düşüktür. Katılımcıların çoğunluğu AİIT dersinin yükseköğretim düzeyinde okutulmasının devam etmesini, içeriğinin ve dersin adının değişmemesini istemektedir. Katılımcılar Atatürk İlkeleri ve İnkılâp Tarihi öğretiminin amaçlarının gerçekleşme düzeyinin orta ve üst düzeyde olduğunu düşünmektedirler. Uzaktan eğitim ile yapılan AIİT derslerinde de öğrencilerin karşılaştıkları sorunlar arasında; derste kullanılan öğretim yöntemlerinin yetersizliği, dersin sınavlara yönelik olarak işlenmesi ve derste kullanılan öğretim materyallerinin yetersizliği dikkat çekmektedir. Düz anlatım yöntemi ve ders kitabı bağımlılığı uzaktan eğitim uygulamasında da devam etmektedir. AİIT dersini uzaktan eğitim yoluyla alan katılımcıların çoğunluğu dersleri düzenli takip etmemekte ve AIIIT dersinde uzaktan eğitim uygulamasının yararlı olmadığını düşünmektedir.

Anahtar kelimeler: Atatürk ilkeleri ve inkılâp tarihi dersi; uzaktan eğitim; üniversite öğrencisi

\section{Giriş}

Dünyanın pek çok ülkesinde olduğu gibi Türkiye Cumhuriyeti’nde de devletin kuruluş felsefesinin genç kuşaklara aktarılması fikri cumhuriyetin ilanından kısa bir süre sonra 1925 y1lında Cumhuriyet döneminin ilk yükseköğretim kurumu olan Ankara Adliye Hukuk Mektebi’nde (Ankara Üniversitesi Hukuk Fakültesi) öğretim programına dâhil edilen "İhtilaller Tarihi" dersi ile hayat bulmuştur. Devletin kuruluş felsefesine bağlı gençler yetiştirme fikrinin en önemli enstrümanlarından biri olan inkılâp tarihi öğretimi süreci günümüze kadar kesintisiz bir şekilde devam etmiştir.

Tarih eğitimi kapsamında lisans eğitimi dâhil bütün kademelerde zorunlu olarak okutulan İnkılâp Tarihi derslerinin Türkiye toplumunun kolektif hafizasına ve milli kimliğine etkileri çok belirgindir (Bileteska, Şahin, \& Şükür, 2013). Salt bir tarih dersi olmaktan ziyade Türkiye Cumhuriyeti'nin varlığını devam ettirme yolunda önemli bir misyona sahip olan Atatürk İlkeleri ve İnkılâp Tarihi (AİTT) dersleri ile cumhuriyetin ilk yıllarından günümüze Türk gençliğine Türk inkılâbının temel felsefesine, Cumhuriyet rejimine, Atatürk ilke ve inkılâplarına yönelik olumlu tutum kazandırmak amaçlanmaktadır. Dersin içeriği ve adında zaman zaman yeniden tanımlanma gereği duyulsa da amacının tarihsel süreç içinde kökten bir değişikliğe uğramadığı görülmüştür (Şimşek \& Güler, 2013).

Kendisine Türkiye Cumhuriyeti'nin kuruluş felsefesinin ve devamlılığına yönelik düşünce dünyasının genç kuşaklara aktarılması gibi hayati bir misyon da

*Sorumlu Yazar: Doç. Dr., Gazi Üniversitesi, Ankara, Türkiye, akbaba@gazi.edu.tr.

***oç. Dr., Kastamonu Üniversitesi, Kastamonu, Türkiye, kaymakci37@yahoo.com.

**** Yrd. Doç. Dr., Gazi Üniversitesi, Ankara, Türkiye, togayar@gmail.com.

***** Yrd. Doç. Dr., Gazi Üniversitesi, Ankara, Türkiye, bahadir@gazi.edu.tr 
yüklenen Atatürk İlkeleri ve İnkılâp Tarihi dersleri, yüksek öğretim kurumlarının tüm bölümlerinde okutulan zorunlu derslerden bir tanesidir. Dersin amaçlarındaki tutarlılık ve dersin tüm yükseköğretim gençliği tarafından zorunlu olarak alınması konudaki birlik, dersin işlenişi hususundaki birliği getirmemektedir (Aksoy, 2006, s. 66). Bu birliğgin olmayışı dersle ilgili tartışmaları farklı boyutlara da taşımaktadır. Akademik camiada, özellikle hukuk, siyaset bilimi ve tarih alanlarındaki bilim insanları arasında daha çok bu dersin nasıl okutulması gerektiği konusunda yapılan tartışmalar günümüze kadar sürmüştür. Kökleri 1925 yılına kadar geriye götürülebilecek bir ders olması ve tarihsel süreç içerisinde yaşanan siyasal gelişmelerin etkisiyle her dönemde yeni düzenlemelerle Türk eğitim tarihindeki varlığını devam ettirmesiyle, Atatürk İlkeleri ve İnkılâp Tarihi dersi birçok defa benzer nitelikteki tartışmaların konusu olmuştur. Eğitim bilimcilerin dersin öğrenme-öğretme sürecine yönelik tartışmalarının yanında, ders ile ilgisi olduğunu düşünen farklı paydaşların dersin varlığı, felsefesi ve amacı üzerindeki tartışmaları da gündemi meşgul etmektedir (Babaoğlu, 2013).

Son yıllarda gerek az gelişmiş ve gelişmekte olan gerekse gelişmiş ülkelerde eğitim sistemlerinin problemlerinin çözümü amacıyla sınıf ortamında yapılan geleneksel eğitim sistemine alternatif eğitim ortamları inşa edilmektedir (Kaya, 2002). Sınıf ortamındaki eğitime alternatif bir yaklaşım olarak düşünülen uzaktan eğitim, kaynak ile alıcıların öğrenme öğretme sürecinin büyük bir bölümünde birbirinden ayrı ortamlarda bulunduğu, zaman ve mekân esnekliği bulunan, kaynak ile alıcılar arasındaki etkileşimin bilişim teknolojileri ile sağlandığı sistematik bir eğitim teknolojisi uygulamasıdır (Uşun, 2006). Uzaktan eğitimin bu işlevi AIİT dersinin uygulamasında yaşanan fiziki mekân problemleri, sınav uygulamalarındaki yetersizlikler, öğretim üyesi eksikliği, dersin öğretim yöntemleri ve öğretim materyallerinin kullanımı konusundaki yetersizlikleri çözme konusunda alternatif bir yol olarak görülmüş ve çeşitli üniversitelerde kullanılmaya başlanmıştır. Aİ̈T derslerinde uzaktan eğitimin uygulanması yüz yüze eğitim kadar etkili olup olmadığı tartışmasını da beraberinde getirmiştir. Yüz yüze eğitim ile yapılan AİIT derslerindeki akademik başarı ve derse yönelik tutumlara ilişkin sınırlı sayıda araştırma bulunmakla birlikte uzaktan eğitimle yapılan AIİT derslerinin etkililiği ve yüz yüze eğitimle verilen AIIIT derslerinin çıktıları ile mukayesesinin yapıldığı bir araştırma literatürde yer almamaktadır. Bu araştırma uzaktan eğitimle yapılan AİiT derslerine yönelik öğrenci görüşlerini ortaya koyması ve bu görüşleri yüz yüze eğitimle yapılan AİIT derslerine yönelik öğrenci görüşleriyle tartışması açısından önem arz etmektedir.

\section{Araştırmanın Amacı}

Bu araştırmanın amacı, Atatürk İlkeleri ve İnkılâp Tarihi (AİIT) dersinin uzaktan eğitim yoluyla öğretimine yönelik öğrenci görüşlerini belirleyebilmektir. Bu amaç doğrultusunda aşağıdaki sorulara yanıt aranacaktır:

1. Uzaktan eğitimle AİIT dersi alan öğrencilerin derse yönelik ilgi ve başarı düzeyleri nedir? 
2. Uzaktan eğitimle AIİT dersi öğrencilerin dersin varlığına ve gerekliliğine yönelik görüşleri nelerdir?

3. Uzaktan eğitimle AİiT dersi alan öğrencilere göre dersin amaçlarının gerçekleşme düzeyine ilişkin görüşleri nelerdir?

4. Uzaktan eğitimle Aİ̈T dersi alan öğrencilerin bu derslerde karşılaştıkları sorunlar nelerdir?

5. Uzaktan eğitimle yapılan AİIT derslerinde kullanılan öğretim yöntemleri ve öğretim materyallerinin kullanım sıklıkları nedir?

6. Uzaktan eğitimle AIIITT dersi alan öğrenciler için bu dersin anlamı nedir?

7. Uzaktan eğitimle AİİT dersi alan öğrencilere göre bu derste uzaktan eğitimin işlevselliği nedir?

\section{Yöntem}

Araştırma, tarama modeli esas alınarak yapılandırılmıştır. Tarama modeli mevcut durumu olduğu gibi yansıtmaya çalışan, araştırmada incelenen birey veya nesneleri kendi koşulları içerisinde değerlendirmeye çalışan bir bilimsel araştırma türüdür (Karasar, 2008). Araştırmada tarama modeli araştırmanın amacına uygunluğu, var olan durumu ortaya koyması, büyük örneklemler üzerinde çalışma olanağı sunması, bir konuya ya da olaya ilişkin katılımcıların görüşleriyle ilgili fikirler vermesi gibi özellikleri nedeniyle kullanılmıştır (Büyüköztürk, Kılıç-Çakmak, Akgün, Karadeniz ve Demirel, 2010).

\section{Evren ve Örneklem}

Araştırmanın evrenini Karadeniz Teknik Üniversitesi Fatih Eğitim Fakültesi ile Karabük Üniversitesi Edebiyat Fakültesi'nde öğrenim gören öğrenciler oluşturmaktadır. Araştırmanın örneklemi, araştırmacıların kendi kişisel birikimleri doğrultusunda evreni yansıttıklarına inanarak örneklem seçme esasına dayanan amaçlı örneklem alma (Balcı, 2001) yoluyla belirlenmiştir. Bu çerçevede araştırmanın örneklemini ${ }^{1}$ KTÜ Fatih Eğitim Fakültesi ile Karabük Üniversitesi Edebiyat Fakültesi'nde öğrenim gören toplam 645 öğrenci oluşturmaktadır. Katılımcıların 459'u (\%71.2) bayan, 186's1 (\%28.8) ise erkektir. Yaş aralığı bağlamında katılımcılar incelendiğinde 20-21 yaş grubu öğrencilerin 299 kişi (\%46.4), 17-19 yaş grubu öğrencilerin 216 kişi (\%33.5), 22-23 yaş grubu öğrencilerin 107 kişi (\%16.6), 24-25 yaş grubu öğrencilerin 19 kişi (\%2.9), 26 yaş ve üzeri öğrencilerin ise 4 kişi $(\% 0.6)$ olduğu belirlenmiştir. Katılımcıların 365'i (\%56.6) genel lise, 169’u (\%26.2) Anadolu Lisesi, 56’s1 (\%8.7) meslek lisesi, 44’ü (\%6.8) Anadolu Öğretmen Lisesi, 6's1 (\%0.9) fen lisesi ve 5'i (\%0.8) kolej mezunudur. Katılımcıların 483'ü (\%74.9) KTÜ Fatih Eğitim Fakültesi'nde, 162'si ise (\%25.1) Karabük Üniversitesi Edebiyat Fakültesi'nde öğrenim görmektedir. Katılımcılardan 478 kişi (\%74.1) 1. sınıf, 105 kişi (\%16.3) 2. sınıf ve 62 kişi ise (\%9.6) 3. sınıf düzeyinde

${ }^{1}$ Araştırmada KTÜ ve Karabük Üniversitesi’nin seçilme nedeni söz konusu üniversitelerde 3 yıllı aşkın bir süredir AİTT derslerinin uzaktan eğitim yoluyla verilmesinden kaynaklanmaktadır. Öte yandan eğitim fakültesi ve edebiyat fakültesinin seçilme nedenleri ise örnekleme ulaşma kolaylığıyla birlikte iki farklı üniversitede katılımcıların bakış açılarındaki benzerlik ve farklılığı görme isteğinden kaynaklanmaktadır. 
lisans öğrenimine devam etmektedir. Katılımcıların akademik başarı durumuna bakıldığında ise 392 kişinin (\%60.7) 2.01-3.00 aralığında, 174 kişinin (\%27.0) 3.013.50 aralığında, 47 kişinin (\%7.3) 2.00'dan az ve 32 kişinin de (\%5) 3.51 ile 4.00 aralı̆̆ında akademik ortalamaya sahip olduğu görülmektedir.

\section{Veri Toplama Aracı ve Geliştirilmesi}

Araştırma verileri Akbaba ve diğerleri tarafından geliştirilen ve son hali Akbaba vd. (2014)’te kullanılan Atatürk İlkeleri ve İnk1lâp Tarihi Anket Formuna uzaktan eğitimin etkililiği bölümü eklenerek toplanmıştır. Akbaba vd. tarafından ilgili literatürün taranmasının ardından oluşturulan Atatürk İlkeleri ve İnkılâp Tarihi Anket Formu madde havuzu kapsam geçerliği için Gazi, Ankara ve Hacettepe Üniversiteleri'nde görev yapan Atatürk İlkeleri ve İnkılâp Tarihi ögretimi konusunda uzmanlaşmış öğretim üyelerinin görüşüne sunulmuştur. Alan uzmanlarının görüşleri doğrultusunda gerekli düzeltmeler yapıldıktan sonra ölçme ve değerlendirme, dil bilimi uzmanlarının da onayı alınan anket formu 2012-2013 eğitim öğretim yılı bahar döneminde Gazi Üniversitesi, Gazi Eğitim Fakültesi'nde öğrenim gören toplam 235 öğrenciye uygulanarak SPSS 15.0 programında güvenirlik analizleri yapılmıştır. Anketin iç tutarlılık katsayısı Cronbach Alpha katsayısı ile hesaplanmıştır. Cronbach Alpha değeri 0.949 olarak hesaplanmış ve bu durum Atatürk İlkeleri ve İnkılâp Tarihi anket formu ile güvenilir ölçümler yapılabileceğini göstermektedir. Güvenirlik katsayının 0.70 ve üzerinde olması, ölçeğin güvenirliğinin bir göstergesi olarak kabul edilmektedir (Sipahi, Yurtkoru, \& Çinko, 2010). Bu araştırmada anket, araştırmanın amacına uygunluğu, daha büyük örneklemler üzerinde çalışma firsatı sağlaması, gözlem ve mülakata göre zaman açısından daha ekonomik olması gibi özellikleri nedeniyle kullanılmıştır (Büyüköztürk vd., 2010).

\section{Verilerin Toplanması ve Analizi}

Araştırmaya ilişkin veriler 2013-2014 eğitim öğretim yılı bahar yarıyılında Karadeniz Teknik Üniversitesi, Fatih Eğitim Fakültesi ve Karabük Üniversitesi Edebiyat Fakültesi'nde öğrenim gören 645 öğrenciden toplanmıştır. Veriler toplanırken araştırmanın amacı, niteliği (bilimsel bir çalışma olması) ve gizliliği (kimlik bilgilerinin saklı tutulacağı) gibi konular hususunda katılımcılar bilgilendirilmiştir. Araştırmada toplanan veriler SPSS 15.0 programı aracılığıyla analiz edilmiştir. Verilerin çözümlenmesinde doğrudan çözümleme bağlamında katılımcı görüşlerinin betimsel istatistiklerine yer verilmiştir.

\section{Bulgular}

$\mathrm{Bu}$ bölümde, araştırmanın bulguları ve bu bulgulara yönelik yorumlar ele alınmıştır. Bulgular ve yorumlar, araştırmanın alt problemleri doğrultusunda elde edilen verilere göre aşağıda değerlendirilmiştir: 


\section{Uzaktan Eğitimle AİİT Dersi Alan Öğrencilerin Derse Yönelik İlgi ve Başarı Düzeyleri}

Araştırmanın birinci alt probleminin analizinde uzaktan eğitimle AIİT dersi alan öğrencilerin derse yönelik ilgi ve başarı düzeylerine ait betimsel istatistik değerleri ele alınmıştır. Bu değerler Tablo 1’de sunulmuşstur:

Tablo 1

Uzaktan Eğitimle AİIT Dersi Alan Katılımcıların Derse Yönelik İlgi ve Başarı Düzeyleri $(N=645)$

\begin{tabular}{|c|c|c|c|c|c|c|c|c|c|c|c|}
\hline \multicolumn{3}{|c|}{$\begin{array}{l}\text { Aİ̈T Konularına } \\
\text { Yönelik İlgi Düzeyi }\end{array}$} & \multicolumn{3}{|c|}{$\begin{array}{l}\text { AIIITT İle İlgili Okunulan } \\
\text { Kitap Sayısı }\end{array}$} & \multicolumn{3}{|c|}{$\begin{array}{l}\text { AİiT Derslerine Devam } \\
\text { Durumu }\end{array}$} & \multicolumn{3}{|c|}{$\begin{array}{l}\text { AIIIT Derslerindeki } \\
\text { Başarı Durumu }\end{array}$} \\
\hline Grup & $f$ & $\%$ & Grup & $f$ & $\%$ & Grup & $f$ & $\%$ & Grup & $f$ & $\%$ \\
\hline Orta & 273 & 42.3 & $1-5$ & 337 & 52.3 & Hiç & 147 & 22.7 & $71-85$ & 310 & 48.0 \\
\hline Çok & 149 & 23.1 & Hiç & 127 & 19.7 & $1 / 4$ & 147 & 22.7 & $86-100$ & 159 & 24.7 \\
\hline $\mathrm{Az}$ & 114 & 17.7 & $6-10$ & 119 & 18.4 & Yarısı & 139 & 21.6 & $51-70$ & 145 & 22.5 \\
\hline $\begin{array}{l}\text { Pek } \\
\text { çok }\end{array}$ & 56 & 8.7 & $11-15$ & 35 & 5.4 & Tamamı & 121 & 18.8 & $\begin{array}{l}50 \text { 'den } \\
\text { az }\end{array}$ & 31 & 4.8 \\
\hline \multirow[t]{2}{*}{ Hiç } & 53 & 8.2 & $16-20$ & 14 & 2.2 & $3 / 4$ & 91 & 14.2 & & & \\
\hline & & & $\begin{array}{l}21 \text { ve } \\
\text { üzeri }\end{array}$ & 13 & 2.0 & & & & & & \\
\hline
\end{tabular}

Tablo 1'e göre uzaktan eğitimle Aİ̇T dersi alan katılımcıların \%74.1'i Atatürk İlkeleri ve İnkılâp Tarihi konularına orta ve üst düzeyde ilgi duyduğunu ifade etmektedir. Bununla beraber bu konuya ilginin göstergelerinden bir tanesi olan konu ile ilgili okuduğu kitap sayısı 21 'in üzerinde olan öğrenci sayısı sadece 13 kişidir. Bu grup $\% 2$ 'lik bir katılımcıyı temsil etmektedir. Katılımcıların Aİ̈T dersine devam durumu incelendiğinde çalışma grubunun \%33'ünün derslerin çoğunluğuna devam ettiği görülmektedir. Katılımcıların AIİT dersindeki başarı durumuna göz atıldığında \%72.7'lik grubun akademik başarı notunun 71-100 puan aralığında olduğu görülmektedir.

\section{Uzaktan Eğitimle AIIITT Dersi Alan Öğrencilerin Aİi̇T Dersinin Varlığı ve İçeriğine Yönelik Görüşleri}

Araştırmanın ikinci alt probleminin analizinde uzaktan eğitimle AIIIT dersi alan katılımcıların dersin varlığına ve gerekliliğine yönelik görüşlerine ait betimsel istatistik değerleri ele alınmıştır. Bu değerler Tablo 2, 3 ve 4’te sunulmuştur.

Tablo 2'ye göre katılımcıların \%77.8'i AİITT dersinin yükseköğretim düzeyinde okutulmasının devam etmesini istemektedir. Öğrencilerin \%49.5'i dersin seçmeli hale dönüştürülmesini istemektedir. Katılımcıların \%72.2'si ders içeriğinin değiştirilmemesini istemektedir. Katılımcıların \%85.9’u dersin adının değiştirilmesini 
istememektedir. Dersin adının değişmesini isteyen katılımcıların dersin adıyla ilgili önerileri arasında Türkiye Cumhuriyeti Tarihi, Modern Türkiye Tarihi, Yeni Türkiye Tarihi, İnkılâp Tarihi ve Devrim Tarihi adları öne çıkmaktadır.

\section{Tablo 2}

Uzaktan Ĕgitimle AİIT Dersi Alan Katılımcıların AİIT Dersinin Varlı̆̆ ve İçeriğine Yönelik Görüşleri $(N=645)$

\begin{tabular}{|c|c|c|c|c|}
\hline \multirow{2}{*}{ İfadeler } & \multicolumn{2}{|c|}{ Evet } & \multicolumn{2}{|c|}{ Hayır } \\
\hline & $f$ & $\%$ & $f$ & $\%$ \\
\hline AIIITT dersi yükseköğretim düzeyinde okutulmaya devam etmeli midir? & 502 & 77.8 & 143 & 22.2 \\
\hline AİIT seçmeli bir derse dönüştürülmeli midir? & 319 & 49.5 & 326 & 50.5 \\
\hline AİİT dersinin içeriği değişmeli midir? & 179 & 27.8 & 466 & 72.2 \\
\hline AİITT dersinin adı değişmeli midir? & 91 & 14.1 & 554 & 85.9 \\
\hline
\end{tabular}

Tablo 3'e göre katılımcıların \%35.7'si dersin haftada üç saat olmasını isterken, \%27.9’luk bir bölüm iki saat, \%16.4'lük bölüm dört saat, \%13.8'lik bölüm 1 saat olmasını istemektedir. AIIITT dersi hiç olmasın diyen katılımcılar ise \%6.2'lik bir grubu oluşturmaktadır. Bu gruptaki katılımcılar Tablo 4'te yer alan dersin gereksizliğine yönelik algının oluşmasına neden olan ifadelere "Evet" diyerek dersin yapılmamasına yönelik isteklerinin sebeplerini ortaya koymuşlardır.

Tablo 3

Uzaktan Eğitimle AİIT Dersi Alan Katılımcların AİIT Ders Saatinin Ne Olması Gerektiğine Yönelik Görüşleri (N=645)

\begin{tabular}{cccc}
\hline Ders Saati Sayısı & $f$ & $\%$ \\
\hline 3 Saat & 230 & 35.7 \\
2 Saat & 180 & 27.9 \\
4 Saat & 106 & 16.4 \\
1 Saat & 89 & 13.8 \\
Hiç Olmamalı & 40 & 6.2 \\
\hline
\end{tabular}

Tablo 4'e göre AİiT dersinin müfredatta yer almasını istemeyen 40 kişiden oluşan ve katılımcıların \%6.2'lik bir bölümünü temsil eden grubun bu düşüncelerinin oluşmasında etkili olan unsurlar arasında dersin akademik başarıya etkisinin olmaması, derste çoklu bakış açılarına yer verilmemesi ve dersin tartışma ve eleştiriden yoksun olduğu düşüncesi öne çıkmaktadır. 
Tablo 4

Uzaktan Eğitimle Aİ̈T Dersi Alan Katılımclların Aİ̈T Dersinin Müfredattan Kaldırılmasına Dair İsteklerine Kaynaklık Eden Problemlere Yönelik Görüşleri N=480)

\begin{tabular}{lcccc}
\hline \multirow{2}{*}{\multicolumn{1}{c}{ İfadeler }} & \multicolumn{2}{c}{ Katılan } & \multicolumn{3}{c}{ Katılmayan } \\
\cline { 2 - 5 } & $f$ & $\%$ & $f$ & $\%$ \\
\hline Çoklu bakış açısına yer verilmemektedir. & 14 & 35.0 & 26 & 65.0 \\
Dersin akademik başarıya bir etkisi yoktur. & 14 & 35.0 & 26 & 65.0 \\
Tartışma ve eleştiriden yoksun bir derstir. & 14 & 35.0 & 26 & 65.0 \\
Resmi ideolojiyi yansıtma dersidir. & 9 & 22.5 & 31 & 77.5 \\
KPSS türü sınavlara hazırlık dersi olarak algılanmaktadır. & 8 & 20.0 & 32 & 80.0 \\
Nesnellikten uzak bir derstir. & 8 & 20.0 & 32 & 80.0 \\
Öğrencilerin demokratik tutum becerilerini geliştirmesini & & & & \\
engellemektedir. & 7 & 17.5 & 33 & 82.5 \\
Statik yapıda bir derstir. & 6 & 15.0 & 34 & 85.0 \\
Öğretmen merkezli olduğundan öğrencinin gelişimine katkısı azdır. & 6 & 15.0 & 34 & 85.0 \\
Lise düzeyinde oluşan sorunlar devam etmektedir. & 5 & 12.5 & 35 & 87.5 \\
Yabancı ülke vatandaşları için gereksiz bir derstir. & 4 & 10.0 & 36 & 90.0 \\
Yükseköğretim seviyesinde gereksiz bir tekrardan ibarettir. & 1 & 2.5 & 39 & 97.5 \\
\hline
\end{tabular}

\section{Uzaktan Eğitimle AİìT Dersi Alan Öğrencilerin AİIT Dersinin Amaçlarının} Gerçekleşme Düzeylerine Yönelik Görüşleri

Araştırmanın üçüncü alt probleminin analizinde uzaktan eğitimle AİiT dersi alan öğrencilerin AIİT dersinin amaçlarının gerçekleşme düzeyine yönelik görüşlerine ait betimsel istatistik değerleri ele alınmıştır. Bu değerler Tablo 5'te sunulmuştur.

Tablo 5'e göre katılımcılar Atatürk İlkeleri ve İnkılâp Tarihi öğretiminin amaçlarının gerçekleşme düzeyinin orta ve üst düzeyde olduğunu düşünmektedirler. Tabloda AIİT dersinin amaçlarının hiç gerçekleşmediğine yönelik en büyük yüzdelik (\%12.2) bireylerin ahlakî gelişimine katkısı ile ilgilidir. Dersin amaçların hiç gerçekleşmediğine yönelik diğer önemli görüş ise dersin bilimsel düşünme becerisi kazandırmaya katkısı (\%11) ile ilgili olan ifadedir. Dersin bilimsel düşünce kazandırmaya katkısı Tablo 7'de sunulan derste karşılaşılan temel sorunlar arasında öne çıkan ifadelerle doğrudan ilgilidir. 
Tablo 5

Uzaktan Eğitimle Aİ̈T Dersi Alan Katılımcıların Aİ̈T Dersinin Amaçlarının Gerçekleşme Düzeylerine Yönelik Görüşleri $(N=645)$

\begin{tabular}{|c|c|c|c|c|c|c|c|c|c|c|}
\hline \multirow{2}{*}{ İfadeler } & \multicolumn{2}{|c|}{ Hiç } & \multicolumn{2}{|c|}{$\mathrm{Az}$} & \multicolumn{2}{|c|}{ Orta } & \multicolumn{2}{|c|}{ Çok } & \multicolumn{2}{|c|}{ Pek çok } \\
\hline & $f$ & $\%$ & $f$ & $\%$ & $f$ & $\%$ & $f$ & $\%$ & $f$ & $\%$ \\
\hline $\begin{array}{l}\text { Bireylerin ahlakî gelişimine katk1 } \\
\text { sağlama }\end{array}$ & 79 & 12.2 & 137 & 21.2 & 221 & 34.3 & 134 & 20.8 & 74 & 11.5 \\
\hline Bilimsel düşünme becerisi kazanma & 71 & 11.0 & 136 & 21.1 & 201 & 31.2 & 150 & 23.3 & 87 & 13.4 \\
\hline Türk dış politikasını analiz edebilme & 51 & 7.9 & 117 & 18.1 & 206 & 31.9 & 157 & 24.4 & 114 & 17.7 \\
\hline Değiş̧imi ve sürekliliği algılama & 43 & 6.7 & 109 & 16.9 & 215 & 33.3 & 165 & 25.6 & 113 & 17.5 \\
\hline Millî hedefler ve idealler kazanma & 41 & 6.4 & 103 & 16.0 & 179 & 27.8 & 185 & 28.7 & 137 & 21.1 \\
\hline $\begin{array}{l}\text { Görev ve sorumluluklarının bilincinde } \\
\text { vatandaşlar yetiştirme }\end{array}$ & 37 & 5.7 & 106 & 16.4 & 225 & 34.9 & 172 & 26.7 & 105 & 16.3 \\
\hline $\begin{array}{l}\text { Türkiye Cumhuriyeti’ni tehdit eden } \\
\text { ortak meselelere dair bilgi edinme ve } \\
\text { duyarlıl1k kazanma }\end{array}$ & 37 & 5.7 & 88 & 13.6 & 194 & 30.1 & 192 & 29.8 & 134 & 20.8 \\
\hline $\begin{array}{l}\text { Siyasi, kültürel, sosyal vb. konularda } \\
\text { değerlendirme yapma }\end{array}$ & 35 & 5.4 & 96 & 14.9 & 234 & 36.3 & 162 & 25.1 & 118 & 18.3 \\
\hline $\begin{array}{l}\text { Cumhuriyetin temel değerlerini } \\
\text { aktarma }\end{array}$ & 32 & 5.0 & 89 & 13.8 & 184 & 28.5 & 172 & 26.7 & 168 & 26.0 \\
\hline $\begin{array}{l}\text { Atatürk'ün fikir ve düşüncelerini } \\
\text { öğrenme }\end{array}$ & 32 & 5.0 & 69 & 10.7 & 172 & 26.7 & 190 & 29.5 & 182 & 28.1 \\
\hline Günümüzü anlama & 30 & 4.7 & 94 & 14.6 & 245 & 38.0 & 183 & 28.4 & 93 & 14.3 \\
\hline $\begin{array}{l}\text { Türkiye Cumhuriyeti’nin siyasî tarihin } \\
\text { öğrenme }\end{array}$ & 29 & 4.5 & 77 & 12.0 & 183 & 28.4 & 196 & 30.4 & 160 & 24.7 \\
\hline Geçmişe dair bilgi edinme & 27 & 4.2 & 58 & 9.0 & 252 & 39.1 & 203 & 31.5 & 105 & 16.2 \\
\hline Tarih bilinci oluşturma & 22 & 3.4 & 73 & 11.3 & 212 & 32.9 & 193 & 29.9 & 145 & 22.5 \\
\hline $\begin{array}{l}\text { Atatürk ilke ve inkılâplarını } \\
\text { öğrenebilme }\end{array}$ & 21 & 3.3 & 69 & 10.7 & 197 & 30.5 & 187 & 29.0 & 171 & 26.5 \\
\hline
\end{tabular}

\section{Uzaktan Eğitimle AİiT Dersi Alan Öğrencilerin AİiTT Dersinde Karşılaşılan} Sorunlara Yönelik Görüşleri

Araştırmanın dördüncü alt probleminin analizinde uzaktan eğitimle AIİT dersi alan öğrencilerin AIİT derslerinde karşılaşılan sorunlara yönelik görüşlerine ait betimsel istatistik değerleri ele alınmıştır. Bu değerler Tablo 6’da sunulmuştur: 
Tablo 6

Uzaktan Ĕ̆itimle AIIIT Dersi Alan Katılımcıların Aİ̈T Dersinde Karşılaşılan Sorunlara Yönelik Görüşleri $(N=645)$

\begin{tabular}{|c|c|c|c|c|}
\hline \multirow{2}{*}{ İfadeler } & \multicolumn{2}{|c|}{ Katılan } & \multicolumn{2}{|c|}{ Katılmayan } \\
\hline & $f$ & $\%$ & $f$ & $\%$ \\
\hline Derste kullanılan öğretim yöntemleri yetersizdir. & 363 & 56.3 & 282 & 43.7 \\
\hline Ders sınavlara yönelik olarak işlenmektedir. & 317 & 49.1 & 328 & 50.9 \\
\hline Derste kullanılan öğretim materyalleri yetersizdir. & 275 & 42.6 & 370 & 57.4 \\
\hline Ders kitapları yetersizdir. & 264 & 40.9 & 381 & 59.1 \\
\hline $\begin{array}{l}\text { Müfredatı yetiştirme kaygısı dersin verimliliğini ve derse olan ilgiyi } \\
\text { azaltmaktadır. }\end{array}$ & 236 & 36.6 & 409 & 63.4 \\
\hline Atatürk'ün fikir ve düşünceleri yeteri kadar aktarılamamaktadır. & 195 & 30.2 & 450 & 69.8 \\
\hline Ders zorunlu olarak okutulmaktadır. & 181 & 28.1 & 464 & 71.9 \\
\hline Dersin öğretim elemanı yetersizdir. & 171 & 26.5 & 474 & 73.5 \\
\hline Bu dersin kredisiz olması dersi olumsuz etkilemektedir. & 162 & 25.1 & 483 & 74.9 \\
\hline Ders saati azdır. & 159 & 24.7 & 486 & 75.3 \\
\hline Öğrenciler bu dersin gerekliliğgine inanmamaktadır. & 151 & 23.4 & 494 & 76.6 \\
\hline Dersin içeriği çok yoğundur. & 141 & 21.9 & 504 & 78.1 \\
\hline Ders içeriğinin belirlenmesinde siyasi eğilimler etkin rol oynamaktadır. & 134 & 20.8 & 511 & 79.2 \\
\hline $\begin{array}{l}\text { Sosyal, fen, sağlık gibi farklı bölümlerde aynı içeriğin sunulması ilgiyi } \\
\text { azaltmaktadır. }\end{array}$ & 134 & 20.8 & 511 & 79.2 \\
\hline $\begin{array}{l}\text { Ders programında siyasi ve askeri olayların ağırlıkta olması bıkkınlık } \\
\text { vermektedir. }\end{array}$ & 114 & 17.7 & 531 & 82.3 \\
\hline $\begin{array}{l}\text { Kitle iletişim araçlarının telkin ve yönlendirmeleri derse olan güveni } \\
\text { olumsuz etkilemektedir. }\end{array}$ & 120 & 18.6 & 525 & 81.4 \\
\hline $\begin{array}{l}\text { Ders içeriğinde güncel konuların da bulunması sağlıklı değerlendirmeleri } \\
\text { engellemektedir. }\end{array}$ & 76 & 11.8 & 569 & 88.2 \\
\hline
\end{tabular}

Tablo 6’ya göre dersi uzaktan eğitimle alan katılımcıların AIİT dersinde karşılaştıkları sorunlar arasında; derste kullanılan öğretim yöntemlerinin yetersizliği (\%56.3), dersin sınavlara yönelik olarak işlenmesi (\%49.1) ve derste kullanılan öğretim materyallerinin yetersizliği (\%42.6) öne çıkmaktadır.

\section{Uzaktan Eğitimle Alınan AİíT Derslerinde Kullanılan Öğretim Yöntemleri}

Araştırmanın beşinci alt probleminin analizinde katılımcıların uzaktan eğitimle aldıkları Atatürk İlkeleri ve İnkılâp Tarihi derslerinde kullanılan öğretim yöntemleri ve öğretim materyallerinin sıkliklarına yer verilmiştir. Bu değerler Tablo 7 ve 8'de sunulmuştur: 


\section{Tablo 7}

Katılımcıların Uzaktan Eğitimle Aldıkları AİIT Derslerinde Kullanılan Öğretim Yöntemleri $(N=645)$

\begin{tabular}{lcccccccccc}
\hline \multirow{2}{*}{ Öğretim Yöntemleri } & \multicolumn{2}{c}{ Hiç } & \multicolumn{2}{c}{ Az } & \multicolumn{2}{c}{ Orta } & \multicolumn{2}{c}{ Çok } & \multicolumn{2}{c}{ Pek çok } \\
\cline { 2 - 11 } & $f$ & $\%$ & $f$ & $\%$ & $f$ & $\%$ & $f$ & $\%$ & $f$ & $\%$ \\
\hline Olay yeri incelemesi-gezi & 448 & 69.5 & 104 & 16.1 & 52 & 8.1 & 31 & 4.8 & 10 & 1.6 \\
Problem çözme & 354 & 54.9 & 143 & 22.2 & 93 & 14.4 & 32 & 5.0 & 23 & 3.6 \\
Proje & 350 & 54.3 & 113 & 17.5 & 99 & 15.3 & 40 & 6.2 & 43 & 6.7 \\
Simülasyon & 344 & 53.3 & 166 & 25.7 & 103 & 16.0 & 23 & 3.6 & 9 & 1.4 \\
Yerel tarih uygulamaları & 319 & 49.5 & 152 & 23.6 & 121 & 18.8 & 31 & 4.8 & 22 & 3.4 \\
Sözlü tarih uygulamaları & 299 & 46.4 & 139 & 21.6 & 129 & 20.0 & 47 & 7.3 & 31 & 4.8 \\
Örnek olay incelemesi & 281 & 43.6 & 177 & 27.4 & 126 & 19.5 & 44 & 6.8 & 17 & 2.6 \\
Gösteri (Demonstrasyon) & 254 & 39.4 & 169 & 26.2 & 161 & 25.0 & 42 & 6.5 & 19 & 2.9 \\
Tartışma & 231 & 35.8 & 171 & 26.5 & 195 & 30.2 & 31 & 4.8 & 17 & 2.6 \\
Soru cevap & 155 & 24.0 & 184 & 28.5 & 220 & 34.1 & 66 & 10.2 & 20 & 3.1 \\
Düz anlatım & 59 & 9.1 & 38 & 5.9 & 97 & 15.0 & 167 & 25.9 & 284 & 44.0 \\
\hline
\end{tabular}

Tablo 7’ye göre katılımcıların uzaktan eğitimle aldıkları AİIT derslerinde en çok tercih edilen öğretim yöntemi düz anlatımdır. AİITT öğretiminde olay yeri incelemesi, problem çözme, proje ve simülasyon en az tercih edilen öğretim yöntemleridir. Özel öğretim yöntemleri başlığı altında değerlendirilen sözlü tarih uygulamaları ve yerel tarih uygulamaları da yeterince kullanılmamaktadır.

Tablo 8'e göre katılımcıların uzaktan eğitimle aldıkları AİITT derslerinde de en çok kullanılan öğretim materyali ders kitabıdır. Dersin öğretimine katkı sağlayacak diğer öğretim materyallerinin hiç kullanılmadığını ifade eden katılımcıların oranı \%34.6 ve üzerindedir. 
Tablo 8

Katılımcıların Uzaktan Eğitimle Aldıkları AİIT Derslerinde Kullanılan Öğretim Materyalleri $(N=645)$

\begin{tabular}{|c|c|c|c|c|c|c|c|c|c|c|}
\hline \multirow{2}{*}{ Öğretim Materyalleri } & \multicolumn{2}{|c|}{ Hiç } & \multicolumn{2}{|c|}{$\mathrm{Az}$} & \multicolumn{2}{|c|}{ Orta } & \multicolumn{2}{|c|}{ Çok } & \multicolumn{2}{|c|}{ Pek çok } \\
\hline & $f$ & $\%$ & $f$ & $\%$ & $f$ & $\%$ & $f$ & $\%$ & $f$ & $\%$ \\
\hline Sinema filmleri & 400 & 62.0 & 138 & 21.4 & 60 & 9.3 & 32 & 5.0 & 15 & 2.3 \\
\hline Müzelik materyaller & 398 & 61.7 & 125 & 19.4 & 84 & 13.0 & 26 & 4.0 & 12 & 1.9 \\
\hline Hatıratlar & 370 & 57.4 & 134 & 20.8 & 95 & 14.7 & 36 & 5.6 & 10 & 1.6 \\
\hline Arşiv belgeleri & 368 & 57.1 & 139 & 21.6 & 91 & 14.1 & 32 & 5.0 & 15 & 2.3 \\
\hline Çoklu ortam araçları & 340 & 52.7 & 164 & 25.4 & 91 & 14.1 & 33 & 5.1 & 17 & 2.6 \\
\hline $\begin{array}{l}\text { Resmi ve özel süreli } \\
\text { yayınlar }\end{array}$ & 336 & 52.1 & 136 & 21.1 & 107 & 16.6 & 50 & 7.8 & 16 & 2.5 \\
\hline Belgesel filmler & 329 & 51.0 & 144 & 22.3 & 125 & 19.4 & 31 & 4.8 & 16 & 2.5 \\
\hline Tarihi romanlar & 303 & 47.0 & 130 & 20.2 & 120 & 18.6 & 64 & 9.9 & 28 & 4.3 \\
\hline Basılı görsel materyaller & 261 & 40.5 & 150 & 23.3 & 155 & 24.0 & 55 & 8.5 & 24 & 3.7 \\
\hline İnternet siteleri & 223 & 34.6 & 116 & 18.0 & 129 & 20.0 & 93 & 14.4 & 84 & 13.0 \\
\hline Ders kitapları & 185 & 28.7 & 94 & 14.6 & 115 & 17.8 & 100 & 15.5 & 151 & 23.4 \\
\hline
\end{tabular}

\section{Uzaktan Eğitimle AİíT Dersi Alan Öğrenciler için Aİi̇T Dersinin Anlamı}

Araştırmanın altıncı alt probleminin analizinde uzaktan eğitimle AİiT dersi alan öğrenciler için bu dersin anlamına ilişkin betimsel istatistik değerleri ele alınmıştır. Bu değerler Tablo 9'da sunulmuştur.

Tablo 9'a göre, dersin, her Türk vatandaşının mutlaka alması gereken, millî birlik ve beraberliğin öneminin anlatıldığı bir ders olduğunu düşünenlerin oranı \%52.6'dır. Milli birlik ve beraberliğin öneminin anlatıldığı bir ders olduğunu düşünenlerin oranı ise \%45.1'dir. AİIT'nin kendileri için hiçbir anlam ifade etmediğini dile getiren katılımcıların oranı \%10.7'dir. Diğer derslerden farkı olmadığı düşünenlerin oran 1 ise $\% 14.1$ 'dir. 


\section{Tablo 9}

Uzaktan Eğitimle AİIT Dersi Alan Katılımcılar İçin AİIT Dersinin Anlamı (N=645)

\begin{tabular}{lcccc}
\hline \multirow{2}{*}{\multicolumn{1}{c}{ İfadeler }} & \multicolumn{2}{c}{ Katılan } & \multicolumn{2}{c}{ Katılmayan } \\
\cline { 2 - 5 } & $f$ & $\%$ & $f$ & $\%$ \\
\hline Her Türk vatandaşının mutlaka alması gereken bir ders & 339 & 52.6 & 306 & 47.4 \\
Milli birlik ve beraberliğin öneminin anlatıldığı bir ders & 291 & 45.1 & 354 & 54.9 \\
Mustafa Kemal Atatürk’ü tanıma aracı & 276 & 42.8 & 369 & 57.2 \\
Yoğun içeriğe sahip ama gerçek amacı ortaya konulamayan bir ders & 226 & 35.0 & 419 & 65.0 \\
İyi vatandaş yetiştirme aracı & 215 & 33.3 & 430 & 66.7 \\
KPSS ve benzeri sınavlara hazırlık & 213 & 33.0 & 432 & 67.0 \\
Zorunlu olduğu için alınan bir ders & 198 & 30.7 & 447 & 69.3 \\
Resmi ideolojiyi yansıtma aracı & 121 & 18.8 & 524 & 81.2 \\
XIX. - XX. Yy. gelişmelerini günümüze aktaran bir ders & 119 & 18.4 & 526 & 81.6 \\
Diploma notunu artırmaya yarayan ara bir ders & 105 & 16.3 & 540 & 83.7 \\
Siradan bir ders & 91 & 14.1 & 554 & 85.9 \\
Hiçbir şey & 69 & 10.7 & 576 & 89.3 \\
\hline
\end{tabular}

\section{Uzaktan Eğitimle AİíT Dersi Alan Öğrencilerin AİíT Derslerinde Uzaktan} Eğitimin İşlevselliğine Yönelik Görüşleri

Araştırmanın yedinci alt probleminin analizinde uzaktan eğitimle Aİ̇T dersi alan öğrencilerin AIIITT derslerinde uzaktan eğitimin işlevselliğine yönelik görüşlerine ilişkin betimsel istatistik değerleri ele alınmıştır. Bu değerler Tablo 10'da sunulmuştur.

Tablo 10'a göre, uzaktan eğitimle AIIITT dersi alan katılımcıların \%89.3'ü dersleri düzenli takip etmemekte, \%87.1'i sınıf arkadaşlarıyla sanal ortamda tarih tartışmaları yapmak, bilgi paylaşmak ve sohbet etmekten hoşlanmamakta, \%76.6's1 ise AIIIT dersinde uzaktan eğitim uygulamasının yararlı olmadığını düşünmektedir. 
Tablo 10

Uzaktan Ĕ̈itimle AİIT Dersi Alan Katılımcıların AIIIT Derslerinde Uzaktan Ĕ̈itimin İslevselliğine Yönelik Görüşleri $(N=645)$

\begin{tabular}{lccccc}
\hline \multirow{2}{*}{\multicolumn{1}{c}{ İfadeler }} & \multicolumn{2}{c}{ Katılan } & \multicolumn{2}{c}{ Katılmayan } \\
\cline { 2 - 6 } & $f$ & $\%$ & $f$ & $\%$ \\
\hline Gereksiz bir uygulama olduğunu düşünüyorum. & 355 & 55.0 & 290 & 45.0 \\
Sınıf atmosferi oluşmadığı için beğenmiyorum. & 306 & 47.4 & 339 & 52.6 \\
Uzaktan eğitim olmasına rağmen ben ders kitabından çalışıyorum. & 304 & 47.1 & 341 & 52.9 \\
$\begin{array}{l}\text { Dersin uzaktan eğitimle olması ders sorumlusuyla iletişimimimi olumsuz yönde } \\
\text { etkiliyor. }\end{array}$ & 285 & 44.2 & 360 & 55.8 \\
Ders içeriğini bildiğim için konu anlatım videolarını seyretmiyorum. & 270 & 41.9 & 375 & 58.1 \\
Devam zorunluluğu olmadığı için derslere katılmıyorum. & 260 & 40.3 & 385 & 59.7 \\
Yararlı olduğunu düşünüyorum. & 151 & 23.4 & 494 & 76.6 \\
Ders saatinde sitede çevrimiçi gözüküyorum; fakat dersi takip etmiyorum. & 114 & 17.7 & 531 & 82.3 \\
$\begin{array}{l}\text { Sinıf arkadaşlarımla sanal ortamda tarih tartışmaları yapmak, bilgi } \\
\text { paylaşmak ve sohbet etmek hoşuma gidiyor. }\end{array}$ & & & & \\
Dersleri düzenli olarak takip ediyorum. & 63 & 12.9 & 562 & 87.1 \\
& 69 & 10.7 & 576 & 89.3
\end{tabular}

\section{Sonuç ve Tartışma}

Araştırmanın sonuçlarına göre, uzaktan eğitimle AIİT dersi alan katılımcıların \%74.1'i Atatürk İlkeleri ve İnkılâp Tarihi konularına orta ve üst düzeyde ilgi duyduklarını ifade etmektedir. Babaoğlu'nun (2013) araştırmasının sonuçları da bu bulguyu destekler niteliktedir. Bu araştırmaya göre, yükseköğretimde okuyan öğrenciler yaygın kanının aksine, dersin içerdiği konulara yönelik ciddi düzeyde ilgi göstermektedirler. Akbaba, Demirtaş, Birbudak ve Kılcan'ın (2014) tarih öğretmeni adaylarıyla yaptıkları araştırmanın sonuçlarına göre, çalışma grubundaki tarih öğretmeni adaylarının \%82.3'ü Atatürk İlkeleri ve İnkılâp Tarihi konularına orta ve üst düzeyde ilgi duyduklarını ifade etmektedir. $\mathrm{Bu}$ durum yüz yüze ve uzaktan eğitim alan yükseköğretim gençliğinin AİIT'ye yönelik ilgi düzeylerinin yüksek olduğu şeklinde yorumlanabilir. Bununla beraber bu konuya ilginin göstergelerinden bir tanesi olan konu ile ilgili okuduğu kitap sayısı 21'in üzerinde olan öğrenci sayısı sadece 13 kişidir. $\mathrm{Bu}$ grup \%2'lik bir katılımcıyı temsil etmektedir. Uzaktan eğitimle AIİT dersi alan çalışma grubunda konu ile ilgili okuduğu kitap sayısı 0-5 aralığında olan grup \% 72 'dir. Ozankaya (1978), tarafından yapılan araştırmada ise bireylerin 58'i (\%8.9) bir kitap, 39'u (\%6) iki kitap, 16’sı (\%2.4) üç kitap, 41’i dört ya da daha çok kitap okuduğunu, 203'ü (\%31.2) o yıl bu konuda hiç kitap okumadığını belirtmiştir. 8 kişi (\%1.2) okudum demiş ancak kitabın adını bildirmemiştir. 287 kişi ise (\%44) soruyu cevapsız bırakmıştır. Bu bulgular Gülmez'in (2003) araştırma sonuçlarıyla da örtüşmektedir. Bu araştırmaya katılan bireylerin \%49.2'si bugüne kadar Atatürk İlkeleri ve İnkılâp Tarihi 
konusunda ders kitabının dışında hiç kitap okumadıklarını ifade etmişlerdir. Öğrencilerin \% 19.6'sı bir tane, \%16.7'si dört ve daha fazla, \%10.3'ü iki tane, \%4.1'i üç tane kitap okuduklarını belirtmektedir. Bu kitaplar arasında \%21'lik oranla ilk siray Nutuk almaktadır. Akbaba'nın (2009) araştırma sonuçlarına göre öğrencilerin \%54.3’ü Atatürk İlkeleri ve İnkılâp Tarihi dersine yönelik 0-5 arasında kitap okuduğunu, \% 7.5'i 6-10, \%8.2'si 11-15, \%5.6's1 16-20, \% 4.4'ü ise 21 'den fazla kitap okuduğunu ifade etmektedir. Akbaba vd.'nin (2014) araştırma sonuçlarına göre çalışma grubundaki tarih öğretmeni adaylarının AİIT konuları ile ilgili okudukları kitap sayısı sınırlıdır. Katılımcıların \% 6.9'u konu ile ilgili hiç kitap okumadığını \% 32.8'i ise 1-5 aralığında kitap okuduğunu belirtmiştir. Bununla beraber bu konuya ilginin göstergelerinden bir tanesi olan konu ile ilgili okunan kitap sayısı 21 'in üzerinde olan öğrenci sayısı sadece 18 kişidir. $\mathrm{Bu}$ grup \%4.3'lük bir tarih öğretmeni adayını temsil etmektedir. Araştırmaların tümü yükseköğretim gençliğinin -öğretmen adayları da dâhil olmak üzere- konu ile ilgili okudukları kitap sayısının oldukça sınırlı olduğunu göstermektedir.

Katılımcıların Aİ̈T dersine devam durumu incelendiğinde çalışma grubunun \%33'ünün derslerin çoğunluğuna devam ettiği görülmektedir. Bu durum sınıf ortamındaki devam zorunluluğu olan AİITT derslerine alternatif olarak görülen uzaktan eğitimle AİITT derslerine öğrenci katılımının düşük olduğunu göstermektedir.

Araştırmanın sonuçlarına göre katılımcıların \%77.8'i AIİT dersinin yükseköğretim düzeyinde okutulmasının devam etmesini istemektedir. Öğrencilerin \%49.5'i dersin seçmeli hale dönüştürülmesini istemektedir. Katılımcıların \%72.2'si ders içeriğinin değiştirilmemesini istemektedir. Katılımcıların \%85.9'u dersin adının değiştirilmesini istememektedir. Dersin adının değişmesini isteyen katılımcıların dersin adıyla ilgili önerileri arasında Türkiye Cumhuriyeti Tarihi, Modern Türkiye Tarihi, Yeni Türkiye Tarihi, İnkılâp Tarihi ve Devrim Tarihi adları öne çıkmaktadır. Akbaba vd.'nin (2014) araştırma sonuçları da bu bulguyu destekler niteliktedir. İlgili araştırmanın çalışma grubundaki tarih öğretmen adaylarının \%79.2'si AİIT dersinin yükseköğretim düzeyinde okutulmasının devam etmesini istemektedir. Tarih öğretmeni adaylarının \%64.4'ü dersin zorunlu ders olarak okutulmasını istemektedir. Katılımcıların yaklaşık yarısı (\%51.2) ders içeriğinin değiştirilmemesini istemektedir. Katılımcıların \%63.9’u dersin adının değiştirilmesini istememektedir. Dersin adının değişmesini isteyen tarih öğretmeni adaylarının dersin adıyla ilgili önerileri arasında Türkiye Cumhuriyeti Tarihi ve İnkılâp Tarihi adları öne çıkmaktadır.

Araştırmada uzaktan eğitim ortamında öğretim elemanı-öğrenci iletişimin senkron olarak sağlandığı uzaktan eğitim yazılımlarında sohbet olarak da nitelendirilen ve dijital ortamda yoklama alınan ders saatlerinin süresine yönelik katılımcı görüşleri incelendiğinde, katılımcıların \%35.7'sinin dersin haftada üç saat olmasını istediği, \%27.9’luk bir bölümün iki saat, \%16.4'lük bölümün dört saat, \%13.8’lik bölümün ise 1 saat olmasını istediği görülmektedir. Aİ̇T dersi hiç olmasın diyen katılımcılar ise \%6.2’lik bir grubu oluşturmaktadır. Ozankaya (1978) tarafından yapılan araştırmaya katılan bireylerin 189'u (\%29) dersin eğitim süresinin uzatılmasının gerektiğini, 26's1 (\%4) dersin eğitim süresinin daha kısa olmasını, 323'ü (\%49.5) mevcut eğitim süresinin 
yeterli olduğunu ifade etmektedir. 15 kişi ise (\%2.3) dersin kaldırılmasını istemektedir. $\mathrm{Bu}$ sonucu destekleyen bir başka araştırma olan Gülmez'in (2003) araştırmasının bulgularına göre Atatürk İlkeleri ve İnkılâp Tarihi dersinin gerekli olup olmadığı konusundaki soruya 809 kişi okutulmalı derken 190 öğrenci dersin okutulmaması yönünde görüş bildirmiştir. Aksoy'un (2003) araştırmasına katılan öğrencilerden 472'si (\% 76.1) Atatürk İlkeleri ve İnkılâp Tarihi Dersinin gerekliliğine evet derken, 35 kişi (\%23.2) kısmen, 113 kişi (\%18.3) ise hayır şeklinde cevap vermiştir. Atatürk İlkeleri ve İnkılâp Tarihi dersinin öğretilebilmesi için ders süresinin yeterli olup olmadığının belirlenmesine yönelik ifadeye öğrencilerin \%33.4'ü hayır, \%14.8'i k1smen, \%51.8'i evet şeklinde cevap vermiştir. Hacettepe Üniversitesi Atatürk İlkeleri ve İnkılâp Tarihi Enstitüsü tarafından 1995-96 bahar yarıyılı sonunda otuz üç bölümden 1008 öğrenciyle gerçekleştirilen araştırmanın sonuçlarına göre derslerin sabah saatlerinde hafta içinde ve iki saatlik bir sürede verilmesi yönünde ortak bir kanaat belirmiştir. Dersin süresinin artırılması fikri ise \%17 oranında kabul görürken, \%66 oranında ise artırılmaması istenmiştir. Dersin süresinin azaltılması \%23 oranında kabul görürken \%57 oranında reddedilmiştir (Yılmaz, 2004). Akbaba'nın (2009) araştırma sonuçlarına göre öğrencilerin \%35.7'si ders saatinin arttırılmasını isterken, \%13.3'ü ders saatinin azaltılmasını istemektedir. Atatürk İlkeleri ve İnkılâp Tarihi ders hiç olmasın diyen öğrenci sayısı 5 kişi olup bu örneklem grubunun \%0.4'üdür. $\mathrm{Bu}$ araştırmanın sonuçlarına göre öğrenciler Atatürk İlkeleri ve İnkılâp Tarihi dersinin haftada iki saat olarak verilmesinin uygun olduğunu düşünmektedirler. Akbaba vd.’nin (2014) araştırma sonuçlarına göre çalışma grubundaki tarih öğretmeni adaylarının \%38'i dersin mevcut uygulamada olduğu gibi haftada iki saat olmasını isterken, \%46.2'lik bir bölüm ders saatinin artırılmasını, \%10.3'lük bölüm bir saate indirilmesini istemiştir. AİİT ders hiç olmasın diyen tarih öğretmeni adayları ise \%5.5'lik bir grubu oluşturmaktadır.

Araştırmanın sonuçlarına göre AİIT dersinin müfredatta yer almasını istemeyen 40 kişiden oluşan ve katılımcıların \%6.2'lik bir bölümünü temsil eden grubun bu düşüncelerinin oluşmasında etkili olan unsurlar arasında dersin akademik başarıya etkisinin olmaması, derste çoklu bakış açılarına yer verilmemesi ve dersin tartışma ve eleştiriden yoksun olduğu düşüncesi öne çıkmaktadır. Akbaba vd.'nin (2014) araştırma sonuçlarına göre ise AIİT dersinin müfredatta yer almasını istemeyen 23 kişiden oluşan ve \%5.5'lik bir grubu temsil eden tarih öğretmeni adaylarının bu düşüncelerinin oluşmasında etkili olan unsurlar sıralamasında dersin resmi ideolojiyi yansıtma aracı olduğu ve nesnellikten uzak bir yapıda olduğu (\%69.6) ilk sirada yer almaktadır. Dersin istenmemesine kaynaklık eden bu iki sebebi tartışma ve eleştiriden yoksun bir ders olması düşüncesi (\%52.2) takip etmektedir.

Araştırmanın sonuçlarına göre katılımcılar Atatürk İlkeleri ve İnkılâp Tarihi öğretiminin amaçlarının gerçekleşme düzeyinin orta ve üst düzeyde olduğunu düşünmektedirler. Bu sonuçla örtüşen bulgulardan bir tanesi Hacettepe Üniversitesi'nde gerçekleştirilen araştırmada elde edilen, AIIITT dersinin, gerek öğrencilerin Türk İnkılâbını anlamalarına, gerekse gelecekteki yaşamlarına yapacağı katkı hakkındaki düşüncelerinin oldukça olumlu olduğu sonucudur (Yılmaz, 2004). Akbaba'nın (2007) 
inkılâp tarihi öğretiminin amaçlarına yönelik araştırmasının bulguları da bu araştırmanın bulgularıyla örtüşmektedir. Akbaba vd.’nin (2014) araştırma sonuçlarına göre tarih öğretmeni adayları da Atatürk İlkeleri ve İnkılâp Tarihi öğretiminin amaçlarının gerçekleşme düzeyinin yüksek olduğunu düşünmektedirler.

Araştırmanın bir başka bulgusuna göre dersi uzaktan eğitimle alan katılımcıların AIİT dersinde karşılaştıkları sorunlar arasında; derste kullanılan öğretim yöntemlerinin yetersizliği (\%56.3), dersin sinavlara yönelik olarak işlenmesi (\%49.1) ve derste kullanılan öğretim materyallerinin yetersizliği (\%42.6) öne çıkmaktadır. Gülmez'in (2003) araştırmasının sonuçları da buradaki bulguları destekler niteliktedir. Öğrencilerin \% 53.2'si derslerin işlenişinde ders kitabı dışında herhangi bir araç-gerecin kullanılmadığını belirtmektedir. Kullanıldığını söyleyenler \%14.6'lık orana sahiptir. Ara sıra kullandığını ifade edenler ise \%18.1'dir.Bu araştırmaya katılan öğrencilerin \%41.2'si derslerde daha fazla araç-gerecin kullanılmasını, ders konuları ile ilgili konferans, panel ve sempozyumların yapılmasını istemektedir. Hacettepe Üniversitesi'nde Aİ̈T derslerinin verimliliğini tespit etmek için yapılan araştırmanın bulguları da buradaki bulgularla örtüşmektedir. $\mathrm{Bu}$ araştırmaya göre, derste düz anlatım ağırlıklı modelden vazgeçilemediği bir gerçektir. Bu durum ders sırasında öğrencinin ilgisini ayakta tutmayı güçleştirmektedir. Ayrıca bu araştırmada ortaya çıkan derse ilişkin en önemli ön yargılardan biri AIIIT'nin “ezber dersi” olduğu yönündedir. Derste verilen bilgilerin içeriğinin ve sunuluş biçiminin hiç değişmediği ve bir süre sonra ilgi çekici olmaktan çıtı̆̆ belirtilmektedir. Bu da yüksek öğretim sıralarında verilecek olan derse bu ön yargı ile başlanması ve dersten beklentinin oldukça düşük olması ile sonuçlanmaktadır (Doğaner, 2005). Akbaba'nın (2008) araştırmasında da Atatürk İlkeleri ve İnkılâp Tarihi dersi genel olarak sınavlara yönelik işlendiği öne çıkan sorunlardan bir tanesi olarak ifade edilmiştir. Aynı araştırmada Atatürk İlkeleri ve İnkılâp Tarihi ders kitaplarının, derste kullanılan öğretim yöntemlerinin ve öğretim materyallerinin eksikliği konusundaki ifadelere katılım düzeyi yüksektir. Akbaba vd. (2014)'nin araştırma sonuçlarına göre, AIIIT dersinde karşılaşılan sorunlar arasında; dersin sınavlara yönelik olarak işlenmesi (\%48.6), derste kullanılan öğretim yöntemlerinin yetersizliği (\%44.0), ders saatinin azlığı $(\% 41.1)$ ve derste kullanılan öğretim materyallerinin yetersizliği (\%40.4) öne çıkmaktadır. Araştırma sonuçları gerek sınıf ortamında yüz yüze gerekse uzaktan eğitimle yapılan AİIT derslerinde benzer sorunların yaşandığını ortaya koymaktadır. Bilişim teknoloji desteğiyle esnek ve alternatif bir öğrenme ortamı olarak düşünülen uzaktan eğitimle yapılan AIİT derslerinde aynı sorunların yaşanması derste yaşanan temel problemlerin kaynaklarının benzer olduğunu ve uzaktan eğitimin de bu problemlere çözüm olmadığını göstermektedir.

Araştırmanın sonuçlarına göre uzaktan eğitimle yapılan Aİ̇T derslerinde de en çok tercih edilen öğretim yöntemi düz anlatımdır. AİiT öğretiminde olay yeri incelemesi, problem çözme, proje ve simülasyon en az tercih edilen öğretim yöntemleridir. Özel öğretim yöntemleri başlığı altında değerlendirilen sözlü tarih uygulamaları ve yerel tarih uygulamaları da yeterince kullanılmamaktadır. Hacettepe Üniversitesi’nde 2003-2004 bahar döneminde gerçekleştirilen araştırmaya göre derste 
kullanılan öğretim yöntem ve tekniklerine bakıldığında düz anlatım yöntemi ilk sıradaki yerini korumakta, ikinci sırada soru-cevap, üçüncü sırada ise tartışma tekniğinin kullanıldığı ifade edilmektedir. Bunları düşük oranlarda olmak üzere araştırma inceleme ve gezi-gözlem teknikleri takip etmektedir. Öğrencilerin \%60’1 dersin yalnız öğretim elemanı tarafindan anlatılmasını istemektedirler. Bu durum derse olan ilginin zayıf olduğunu ve bazı önyargılarla derse başlandığını göstermektedir. Öğrencilerin \%73’ü dersin soru-cevap şeklinde işlenmesi gerektiğini düşündüklerini ifade etmişlerdir. Katılımcıların \%17'si ise soru-cevap yönteminin uygulanmasına karşı çıkmıştır (Doğaner, 2005). Akbaba'nın (2008) araştırma sonuçlarına göre Atatürk İlkeleri ve İnk1lâp Tarihi dersinin çoğunlukla düz anlatım yöntemiyle işlendiği ifade edilmektedir. Akbaba'nın (2009) araştırma sonuçlarına göre Atatürk İlkeleri ve İnkılâp Tarihi dersinde kullanılan öğretim yöntemleri içinde en çok kullanılanı düz anlatım yöntemidir. Düz anlatım yönteminden sonra en çok kullanılan öğretim yönteminin sorucevap olduğu görülmektedir. Bu yöntemi sırasıyla örnek olay incelemesi, tartışma, problem çözme, gösteri, olay yeri incelemesi ve drama yöntemi takip etmektedir. Akbaba vd.'nin (2014) araştırma sonuçlarına göre AİITT öğretiminde karşılaşılan problemler arasında öğretim yöntemleri ve öğretim materyallerinin kullanımındaki tekdüzelik ön plandadır. AIİT derslerinde en çok tercih edilen öğretim yöntemi düz anlatımdır. AIİT öğretiminde drama, simülasyon ve olay yeri incelemesi en az tercih edilen öğretim yöntemleridir. Özel öğretim yöntemleri başlığı altında değerlendirilen sözlü tarih uygulamaları ve yerel tarih uygulamaları da yeterince kullanılmamaktadır. Öğrenme-öğretme ortamı farklılaşsa da AİiT derslerinde öğretim elemanlarının aktif, öğrencilerin ise pasif dinleyici konumunda bulunduğu düz anlatım yönteminin hâkimiyeti devam etmektedir. Dersin öğretiminde katkı sağlayacak diğer öğretim yöntemlerinin kullanım sıklığı ise yüz yüze eğitim ortamında olduğu gibi uzaktan eğitim ortamında da beklenilen düzeyde değildir.

Araştırmanın sonuçları uzaktan eğitimle yapılan Aİ̇T derslerindeki öğretim yöntemlerinin kullanımı konusundaki tekdüzeliğin öğretim materyallerine de yansıdığını göstermektedir. Uzaktan eğitimle yapılan AİITT derslerinde de öğrenciler ana kaynak olarak ders kitabını kullanmaktadır. Dersin öğretimine katkı sağlayacak diğer öğretim materyallerinin hiç kullanılmadığını ifade eden katılımcıların oranı \% 34.6 ve üzerindedir. Ozankaya (1978) tarafından yapılan araştırmaya katılan bireylerin 519'u (\%79.6) derste görsel-işitsel öğretim araçlarından çok seyrek ya da hiç kullanılmadığını ifade etmiştir. Hacettepe Üniversitesi'nde 2003-2004 bahar döneminde gerçekleştirilen araştırmaya göre dersin işlenişi sırasında görsel işitsel materyallerden faydalanılması gerektiği konusunda ciddi bir uzlaşma bulunmaktadır. Öğrencilerin \%92'si bu fikre katılmaktadır (Doğaner, 2005). Gülmez'in (2003) yaptığı araştırmaya katılan bireylerin \%53.2'si derslerin işlenişinde ders kitabı dışında herhangi bir araç-gerecin kullanılmadığını belirtmektedir. Farklı öğretim materyallerinin kullanıldığını söyleyenler \%14.6'l1k orana sahiptir. Ara sıra kullandığını ifade edenler ise \%18.1'dir. Öğrencilerin \%41.2'si derslerde daha fazla teknolojik araç-gereç kullanılmasını istemektedir. Akbaba’ya (2009) göre Atatürk İlkeleri ve İnkılâp Tarihi dersinde kullanılan öğretim materyalleri içinde en çok kullanılanı ders kitabıdır. Ders kitabından 
sonra en çok kullanılan öğretim materyalinin tarihî romanlar olduğu görülmektedir. Tarihî romanları sırasıyla basılı görsel materyaller, hatıratlar-biyografiler, belgesel filmler, müzelik malzemeler ve arşiv belgeleri takip etmektedir. Yükseköğretimde tek bir kaynağa bağlı ders yapmanın sakıncaları sürekli dile getirilmesine rağmen ders kitabının tarih derslerinin temel öğretim materyali olma durumu devam etmektedir. Akbaba vd.’nin (2014) araştırma sonuçlarına göre AIİT öğretiminde hâlen en çok kullanılan öğretim materyali ders kitabıdır. Dersin öğretimine katkı sağlayacak diğer öğretim materyallerinin hiç kullanılmadığını ifade eden tarih öğretmeni adaylarının oranı \%30 ve üzerindedir. Aksoy'un (2003) araştırmasının sonuçları bu AIIIT öğretiminde materyal kullanımı konusunda benzer görüşlerin yer aldığı yukarıdaki araştırmaların bulgularıyla örtüşmemektedir. $\mathrm{Bu}$ araştırmaya göre öğrencilerin $\% 5$ 'i Atatürk İlkeleri ve İnkılâp Tarihi dersinin daha ilgi çekici hale getirilebilmesi için materyal kullanılması gerektiği görüşünü ifade etmektedir. Öğretim elemanlarının yaklaşık \%80'i Atatürk İlkeleri ve İnkılâp Tarihi dersinin etkili bir şekilde yürütülebilmesi için sözlü anlatım yönteminin kullanılması gerektiğini düşünmektedir. Önerilen diğer bir yöntem ise yaklaşık \%11 ile soru cevap yöntemidir. Öğretimde yöntemler konuya, öğrenciye, sınıf büyüklüğüne, öğretim elemanının yöntemi kullanma becerisine göre değişmekte ve seçilmektedir. Öğretim elemanlarının getirdikleri bu görüşlerde, geleneksel öğretim yöntemlerine göre yetişme ve bu yöntemlerin kullanımına yatkın olma nedenlerinin etkisi olduğu düşünülmektedir.

Araştırmanın sonuçlarına göre dersin, her Türk vatandaşının mutlaka alması gereken bir ders olduğunu düşünenlerin oran1 \%52.6'dır. Milli birlik ve beraberliğin öneminin anlatıldığı bir ders olduğunu düşünenlerin oranı ise \%45.1'dir. AİIT'nin kendileri için hiçbir anlam ifade etmediğini dile getiren katılımcıların oranı \% 10.7 'dir. Diğer derslerden farkı olmadığı düşünenlerin oranı ise \%14.1'dir. Gülmez'in (2003) araştırma sonuçlarına göre dersin okutulmasının gerekliliğine inanan bireylerin \% 28'i iyi vatandaş ve Atatürkçü bir gençliğin yetiştirilmesinde, böyle bir derse gereksinim olduğunu ifade ederken, \%20'si ise “tarihini bilmeyen geleceğini bilemez” şeklindeki yoruma katılmışlardır. Aksoy’un (2003) araştırmasına göre öğrencilerin \%53.7’si Atatürk İlkeleri ve İnkılâp Tarihi dersinin, öğrenciye millî kimlik ve millî hedef kazandırmada kısmen etkili olduğu, \%21.1'i etkili olduğu, \%17.4'ü etkili olmadığ görüşündedir. Öğrencilerin \%47.1'i öğrenciye iç ve dış tehditler konusunda bilgi kazandırmada dersin k1smen etkili olduğu, \%26.1'i etkili olduğu, \%26.8’i etkili olmadığı görüşündedir. Akbaba'nın (2008) araştırma sonuçlarına göre Gazi Üniversitesi'nde öğrenim gören yükseköğretim gençliğinden seçilen örneklem grubunun çoğunluğu Atatürk İlkeleri ve İnk1lâp Tarihi dersinin gerekliliğine inanmaktadır. Akbaba'nın (2009) araştırma sonuçlarına göre, Atatürk İlkeleri ve İnkılâp Tarihi dersi öğrencilerin eğitim-kültür hayatlarında, siyasî fikirlerinin oluşmasında, Mustafa Kemal Atatürk ile ilgili düşüncelerinin oluşumunda, günümüzü anlamada, ülkemizin geleceği ile ilgi düşüncelerinin oluşumunda ve $A B$ ile ilgili düşüncelerinin şekillenmesinde etkili bir unsur olarak görülmektedir. 
Akbaba vd.'nin (2014) araştırma sonuçlarına göre AİiT dersinin Mustafa Kemal Atatürk'ü tanımaya katkı sağladığını düşünenlerin oranı \%44.7'dir. Her Türk vatandaşının mutlaka alması gereken, millî birlik ve beraberliğin öneminin anlatıldığı bir ders olduğunu düşünenlerin oranı \%43.8'dir. KPSS türü sınavlara hazırlık amacı güttüğünü düşünenlerin oranı ise \%28.9'dur. AİİT'nin kendileri için hiçbir anlam ifade etmediğini dile getiren tarih öğretmeni adaylarının oranı \%12.2'dir. Diğer derslerden farkı olmadığı düşünenlerin oranı ise \%12.7'dir.

Araştırmanın odağını oluşturan AİiT derslerinin uzaktan eğitimle yapılmasının işlevselliğine yönelik katılımcı görüşleri incelendiğinde uzaktan eğitimle AİiTT dersi alan katılımcıların \%89.3'ünün dersleri düzenli takip etmediği, \%76.6'sının ise AIIIT dersinde uzaktan eğitim uygulamasının yararlı olmadığını düşündüğü görülmektedir. Yükseköğretim kurumlarında AİİT derslerinin öğretiminde karşılaşılan fiziki mekân problemleri, öğretim elemanı eksikliği, öğretim yöntemi ve öğretim materyali eksiklikleri, ortak sınavlar için ortak bir bilgi havuzu oluşturma çabası gibi problemlerin üstesinden gelebilmek amaciyla kullanılan uzaktan eğitim sistemi dersin yüz yüze öğretimindeki anlayıştan uzaklaşılamadığı için katılımcılar tarafından benimsenmemiştir. Derse ilgi düzeylerinin yüksek olduğu görülen katılımcıların Aİ̈T dersinin uzaktan eğitimle verilmesini işlevsiz bulmalarında bilişim teknolojisinin sunduğu imkânların yeterince kullanılamaması, öğretim elemanlarının bilgi transfer eden kaynak rollerinden kurtulamamaları, öğretim yöntemleri ve materyallerinin kullanımındaki kısırlık gibi unsurlar etkili olmaktadır. Araştırma örneklem sayısının evrene göre küçük olması, araştırma sonuçlarının geniş genellemelerle açıklanmasını zorlaştırmaktadır; ancak ulaştığı sonuçlar açısından araştırma üniversite öğrencilerinin uzaktan eğitimle AITT derslerinin işlevselliği ve mevcut durumdaki öğretim durumuna ilişkin görüşlerini ortaya koyması açısından önem arz etmektedir.

\section{Öneriler}

Araştırma sonuçları doğrultusunda şu önerilerde bulunulabilir:

- Özellikle sosyal bilgiler, tarih öğretmenliği ve tarih lisans programları gibi AİTT'nin doğrudan öğretimiyle ilgilenen bölümlerde uzaktan eğitimle dersin veriliş durumunu ortaya koymak ve uzaktan eğitimin işlevselliğini belirlemek amacıyla araştırma geniş örneklemler üzerinde tekrarlanmalıdır.

- Uzaktan eğitimle ders veren öğretim üyesi ve elemanlarının konuya ilişkin görüşleri derinlemesine yapılacak araştırmalarla ortaya konulmalıdır.

- Uzaktan eğitimle yapılan AIIITT derslerin teknolojiye bağımlılığı yüksek olan genç kuşaklar için daha ilgi çekici ve işlevsel hâle getirilmelidir.

- Uzaktan eğitimle yapılan AİITT derslerinde bilişim teknolojilerinin sunduğu imkânlar kullanılmalıdır.

- AİIT derslerine giren öğretim elemanlarının bilişim teknolojisi okuryazarı olmaları gerekmektedir. 
- Uzaktan eğitim ortamındaki AIIIT derslerine ilgiyi artırabilmek ve dersin amaçlarının gerçekleşmesine katkı sağlayabilmek için dersin öğretiminde sınav kaygılarından uzaklaşılmalı; çağdaş öğretim yaklaşımları kullanılmalıdır.

- Uzaktan eğitim ortamında yapılan AİiT derslerinde öğretim yöntemi ve öğretim materyali kullanımı konusunda çeşitliliğe gidilmelidir.

- Uzaktan eğitim ortamında yapılan dersler çevrimiçi bilgi paylaşımı, sohbet, etkileşimli proje, belge analizi, görsel kaynak kullanımı, dijital arşivlerden yararlanma gibi etkinliklerle zenginleştirilmelidir.

\section{Kaynakça}

Akbaba, B. (2007). Atatürk ilkeleri ve inkılâp tarihi dersinin amaçlarına yönelik öğrenci görüşleri. Kastamonu Eğitim Dergisi, 15(1), 339-352.

Akbaba, B. (2008). Atatürk ilkeleri ve inkılâp tarihi dersinin öğretiminde karşılaşılan sorunlar (gazi üniversitesi örneği). Gazi Akademik Bakış Dergisi, 1(2), 177-197.

Akbaba, B. (2009). Atatürk ilkeleri ve inkılâp tarihi dersinin öğretimine yönelik bir durum değerlendirmesi (Gazi Üniversitesi örneği). Türkiye Sosyal Araştırmalar Dergisi, 13(1), 29-52.

Akbaba, B., Demirtaş, B., Birbudak, T.S., \& Kılcan, B. (2014). Tarih öğretmeni adaylarının Atatürk ilkeleri ve inkılâp tarihi öğretimine yönelik görüşleri. Journal of World of Turks, 6(2), 207-226.

Aksoy, İ. (2003). Yükseköğretim kurumlarında inkılâp tarihi öğretimi (Yayımlanmamış doktora tezi). Gazi Üniversitesi Eğitim Bilimleri Enstitüsü, Ankara.

Aksoy, İ. (2006). T.C. inkılâp tarihi ve Atatürkçülük dersi konularının yükseköğretimde öğretimi. İçinde Y. Doğaner (Ed.), Türk Eğitim Sisteminde Atatürkçülük ve Türkiye Cumhuriyeti Tarihi Öğretimi (s. 63-71). Ankara: Hacettepe Üniversitesi Yayınları.

Babaoğlu, R. (2013). Yükseköğretimde “Atatürk ilkeleri ve ink1lâp tarihi” dersi (amaç, kapsam ve güncel tartışmalar 1şığında). Tarih Okulu Dergisi (TOD), 6 (XVI), 589603.

Balcı, A. (2001). Sosyal bilimlerde araştırma. Ankara: Pegem.

Biletska, Y., Şahin, C., \& Şükür, İ. (2014). Kolektif hafıza ve milli kimlik bağlamında Türkiye'de resmi tarih yazıcılığı. Insan ve Toplum Bilimleri Araştırmaları Dergisi, 3(1), 94-116.

Büyüköztürk, Ş., Kılıç-Çakmak, E., Akgün, Ö. E., Karadeniz, Ş., \& Demirel, F. (2010). Bilimsel araştırma yöntemleri. Ankara: Pegem.

Doğaner, Y. (2005). Yükseköğrenimde Atatürk ilkeleri ve inkılâp tarihi dersinin öğretiminde karşılaşılan problemler ve yeni yaklaşımlar. Atatürk Araştırma Merkezi Dergisi, 21(62), 589-611.

Gülmez, N. (2003). Üniversite gençliğinin Atatürk ilkeleri ve inkılâp tarihi dersine bakış1. Atatürk Araştırma Merkezi Dergisi, XIX(57), 1043-1088.

Karasar, N. (2008). Bilimsel araştırma yöntemi. Ankara: Nobel. 
Kaya, Z. (2002). Uzaktan eğitim. Ankara: Pegem.

Ozankaya, Ö. (1978). Türk devrimi ve yükseköğrenim gençliği, Ankara: A.Ü. SBF Yayınları.

Şimşek, A. ve Güler, M. (2013). Öğretmen ve öğretmen adayı görüşlerine göre lise Atatürk ilkeleri ve inkılâp tarihi dersinin öğretiminde yaşanan sorunlar ve çözüm önerileri. Adlyaman Üniversitesi Sosyal Bilimler Enstitüsü Dergisi, 6(14), 543-575.

Sipahi, B., Yurtkoru, E. S., \& Çinko, M. (2010). Sosyal bilimlerde SPSS’le veri analizi. İstanbul: Beta.

Uşun, S. (2006). Uzaktan eğitim. Ankara: Nobel.

Yılmaz, M. (2004). Eğitim bilimi ve bilim teknolojisi ışığında yeni yöntem arayışları. İçinde B. Yediyıldız vd. (Eds.), Atatürk Illkeleri ve Inkılap Tarihinde Yöntem Arayışları (s. 100-111). Ankara: Hacettepe Üniversitesi Atatürk İlkeleri ve İnk1lap Tarihi Enstitüsü Yayınları. 